\title{
Exploring the Politics of Widowhood in Vrindavan: An Analysis of Life Narratives of Vrindavan Widows
}

\author{
Urvija Priyadarshini, Rekha Pande* \\ Centre for Women's Studies, University of Hyderabad, Hyderabad, India \\ Email: urvipriya@gmail.com, panderekha@uohyd.ac.in
}

How to cite this paper: Priyadarshini, U., \& Pande, R. (2021). Exploring the Politics of Widowhood in Vrindavan: An Analysis of Life Narratives of Vrindavan Widows. Advances in Applied Sociology, 11, 158-176. https://doi.org/10.4236/aasoci.2021.114012

Received: March 19, 2021

Accepted: April 13, 2021

Published: April 16, 2021

Copyright $\odot 2021$ by author(s) and Scientific Research Publishing Inc. This work is licensed under the Creative Commons Attribution International License (CC BY 4.0).

http://creativecommons.org/licenses/by/4.0/

\begin{abstract}
The experience of Hindu widowhood in the Indian context constitutes social exclusion and marginalization of the woman who has lost her husband. The practice, which is the product of intersection of Indian patriarchy with the Hindu caste system, aims at total obliteration of the widow and rendering her invisible. The widow who is already in a precarious position due to adverse socio-economic and cultural ramifications of being a woman in the Indian society is pushed further to the margins. Her only recourse to means of dignified survival is to conform to the norms of Hindu widowhood that entail curtailment of freedoms associated with dress code, diet, social relationships and sexual conduct. The present paper intends to shed light on the workings of widowhood phenomenon in Vrindavan, Uttar Pradesh, a revered place due to its prominence in Hinduism. A life of religiosity in Vrindavan offers itself as a viable option for widows' subsistence. Vrindavan, in turn, benefits from the presence of widows. The dynamics of the interrelationship between the spiritual economy of Vrindavan and life of widows is explored to shed light on the negotiations that widows undertake on a day-to-day basis to further their existence. Life narratives of widows are analyzed to shed light on the bargains that they undertake to become and survive as a Vrindavan widow.
\end{abstract}

\section{Keywords}

Widowhood, Hinduism, Gender, Religion

\section{Introduction}

Widowhood is a universal phenomenon across diversity of time, cultures and geographical boundaries. There are stark commonalities between sufferings and

${ }^{\star}$ Head, Centre for Women's Studies, University of Hyderabad, Hyderabad, India. 
oppression of widows across the world; her marginalization is tied to the patriarchal supposition that a woman is a complete human being only under the aegis of male guardianship-father, brother, husband or the son; in absence of whom she is an entity to be loathed, be wary of or to be looked upon with doubt and fear. At the same time there are multiplicities of cultural practices that mark widowhood phenomenon in diverse contexts.

In the Indian context a widow in Hindu religion occupies the lowest position in Hindu social order (Das, 1886). In Hindi (language spoken by majority of Indians) the word widow translates into vidhwa meaning the one bereft of her sovereign (Macdonell, 1929). The peculiarity of the Hindu widowhood experience, especially an upper-caste one is the severity of cruelty and social ostracism that the widow is subjected to. She is still considered married to the deceased husband (Clémentin-Ojha, 1988) and is inevitably held accountable for the death of her husband even though he might have died of illness, old age or any other affliction. His death is acutely reflective of failure of her wifely duties in actions, deeds and even thoughts. The extremity of social ostracism is reflected in abandonment of widows in cities considered holy in Hinduism such as Haridwar and Varanasi where she is to perpetually mourn the death of her husband and atone her sins till the end of her life.

Widowhood phenomenon in different cultural settings has varied political and historical trajectories inevitably tied to the histories and political processes of local contexts in which laws, debates and inquiries around widowhood take shape. The politics of Hindu upper-caste widowhood in India is uniquely linked to processes of reproduction and perpetuation of caste system, an inherent system of social organization of Hindu society as enshrined in Hinduism and the politics of colonial occupation of the Indian subcontinent under British rule. The edifice of the caste system was established and codified to perpetuate the supremacy of the Brahmin (upper-most caste) man through exploitation of women's bodies, labor and sexuality in addition to subjugation of lower caste men. The caste system created abominable life conditions for Hindu women in the form of child brides, child widows and satis (women burnt on the funeral pyre of the husband). The imperial forces exploited the pitiable image of the Hindu woman especially the widow as a justification for colonial occupation of the sub-continent, a phenomenon that Spivak famously terms as "white men saving the brown women from brown men" (1994: p. 93). The spate of debates, laws and public actions that followed between the colonial forces and the Indian educated elite utilized the portrayal of miserable Hindu widow adeptly for furthering their own agenda of colonial occupation and counter-agenda of reclamation of freedom from British rule. However, the debates raged without bringing about any drastic changes in her actual living conditions. Thus, as Mayo rightly observes, "the British administration of India, be it good, bad, or indifferent, has nothing whatever to do with the conditions [of India]." (2000: p. 78) The condition of Hindu widows continues to be lamentable despite passing of laws such as ban on child marriage, abolition of sati and widow remarriage act. 
The lived realities of widows in holy cities are a relatively unexplored field of inquiry especially from the perspective of feminist engagement with religion. This paper aims at examining the politics of widowhood in Vrindavan, a town in Uttar Pradesh, India through an analysis of life histories of Vrindavan widows. This subset of widows constitutes an extremely vulnerable community due to the oppressive experience of being a Hindu widow. She is the by-product of an ancient and rigid caste system whose status has remained relatively unchanged from ancient times, through colonial occupation of India, the struggle for independence and the subsequent modernization process. Economic advancement has only served to exacerbate the complications of her existence; with the decrease in household incomes families are not in a position to care for an ageing widowed woman. Several of these women end up in the town of Vrindavan which is called the city of widows due to their ever increasing presence.

The socio-economic, cultural and spiritual ethos of a place has profound gendered effect on the construction of culturally specific femininities. In turn, cultural formations of gender and gender relations profusely impact the social construction and representation of a region (Massey, 2013). This dynamic interplay is evident in the interrelationship between spiritual economy of Vrindavan and panning out of phenomenon of Hindu widowhood in the town. Vrindavan is of great significance to Hindus due to its association with Krishna, a prominent Hindu deity. Widows come to Vrindavan in search of a life of dignified survival free from the afflictions that widowhood confers upon them. They come under the assumption that Krishna will take care of them and alleviate their woes. Vrindavan, in turn, is elevated in its status as a holy spiritual town from being the mere playground of Krishna to the land that provides for and protects the vulnerable widows and fulfills their vision of leaving their bodies behind in death on a sacred land. Life in Vrindavan is expected to be a routine of devout religiosity while conforming to the norms of Hindu widowhood. The narratives of Vrindavan widows reveal the politics of piousness as experientially encountered, lived and negotiated in the process of spending their lives in the town. Narratives also divulge that widowhood is performative in Vrindavan as a widow's survival depends on how best she can "act" (Ganapathy, 2019).

\section{Foregrounding the Hindu Upper Caste Widowhood Experience}

The various dimensions of Hindu upper-caste widowhood experience have been extensively researched and aptly theorized (see Chakravarti, 1995; Chen, 1998; Mani, 1998; Rajan, 1993; Wadley, 1995). Ambedkar (1979) foregrounds the rationale for oppression of widows in the Hindu caste system. According to him the perpetuation and maintenance of caste hierarchy in Hindus is ensured by the system of endogamous marriage, a practice that ought to repeat without disruptions generation after generation. In reality, this is seldom the case since the average age difference between the husband and wife is invariably substantial which often results in the death of the husband earlier than the wife. The "sur- 
plus" woman that is left behind poses a threat to the caste hierarchy since her sexuality bears the potential of sexual union with a man of a different caste; a union that could pollute the stratification of the caste structure. The now obliterated practice of Sati or ceremonial burning of the widow on the funeral pyre of the husband constituted a contemptible measure to deal with the problem of the surplus woman. The other measure adopted that has survived and continues to thrive through the history of the subcontinent is the practice of enforced celibacy (Chakravarti \& Gill, 2001). Celibacy, according to Olson (2008), is the means to control and discipline the body and its sexual urges. It is a form of violence inflicted upon the self in case of voluntary celibacy or violence on self, embodied within a religious institution to ascribe membership to a certain religious group. The rules of celibate widowhood are enshrined in religious texts of Hinduism. Manusmriti, a contentious treatise delineating codified Hindu laws to govern Hindu way of life enumerates strictures for widows. A verse in Manusmriti as delineated below demonstrates the severity of austerity expected from Hindu widows.

"When her husband is dead she may fast as much as she likes, (living) on auspicious flowers, roots and fruits, but she should not even mention the name of another man. She should be long suffering until death, self-restrained and chaste, striving (to fulfill) the unsurpassed duty of women who have one husband.” (Chakravarti \& Gill, 2001: p. 37)

The strictures of celibate Hindu widowhood govern a widow's diet, modes of dressing and sexual and behavioral conduct. Dietary restrictions include abstinence from consumption of meat, spices, sweets, excessively oily or rich food, and according to some texts even some varieties of lentils; articles that could potentially generate heat in her body and awaken her sexual urges. She is to consume food only two times during the day before sunset. Appropriate dress code entails abstinence from wearing colored clothes and only wearing white garb, abstinence from wearing jewelry, refrain from engaging in any act of self-beautification such as wearing collyrium in the eyes and refrain from wearing any markers of a married woman such as the sindoor (red vermillion), mangalsutra (sacred black beaded thread), toe rings and shaakha (white bangles made of conch shell). She is to abstain from sexual indulgences not only in actions but also in thoughts since the mere thought of it can ruin her allegiance and loyalty to her dead husband.

The violence of enforced celibacy is intended to slowly and steadily annihilate the Hindu widow. She is denuded of her personhood upon the death of her husband. From being addressed to as a woman she becomes an "it". The restrictions of diet aim at continuous emaciation of her body by devoiding it of any strength producing nutrition. Abstinence from wearing colors and any act of self-beautification aims at desexualizing and making the widowed-self least desirable to the male gaze. In the past, several barbaric ritual practices were associated with mourning the death of the husband such as shaving widow's head, breaking her bangles and tearing out ornaments that adorned her body. A sepa- 
rate space was allotted to her in the house with minimal or no amenities such as a soft bed thus minimalizing any comfort. From the auspicious suhagan (a happily married woman) she was rendered the epitome of inauspiciousness and impurity. Her mere shadow was to be avoided since her very presence entailed bad luck. Consider the following verse about widow as delineated in an $18^{\text {th }}$ century Hindu text Stridharmapaddhati "Just as the body, bereft of life, in that moment becomes impure, so the woman bereft of her husband is always impure, even if she has bathed properly. Of all inauspicious things, the widow is the most inauspicious; there can never be any success after seeing a widow" (Leslie, 1995: p. 303)

Chakravarti and Preeti consider these "codes of bodily mortification, food restrictions, symbolic relationships with colors, dress and access to spaces and ceremonies", the customary obligations of enforced widowhood entailing the "social death" of Hindu upper caste widow (2001: p. 7). Her social death translates into loss of social identity, social-economic and cultural capital, social networks, social exclusion and exclusion from access to resources (Králová, 2015).

\section{Indian Widowhood-Issues of Representation and Need for Newer Inquiries}

Shandilya (2017: p. 5) considers the widow figure to be a highly contested one in South Asia since her voice has been subsumed by the discourses of "imperial legal structures" and "brahminical scriptural readings". Distinct group of practices existed within the purview of widowhood in India-niyoga (now obliterate practice of levirate marriage of the widow), sati, re-marriage and celibacy out of which sati and re-marriage are on the brink of over-analysis due to the politics of the colonial discourse. Niyoga has faded into the oblivion just like the practice itself. It is the celibate widow that continues to beg further investigation due to her continuance through ancient times into the present day and since celibacy continues to constitute the reality of lives of a large number of Hindu widows in India. Spivak notes in the context of colonial debates that "there was no debate upon this exceptional fate of widows [i.e. celibacy] - either among Hindus or between Hindus and British" (Rajan, 1993: p 52). Thus Shandilya's assertion of widows being the object rather than the subject of analysis rings true.

The task of delineating a systematic history of widowhood in India remains sporadic and incomplete. Representation of widows-both historical and contemporary has lopsidedly exacerbated her vulnerabilities and has constructed her as the eternal victim. The continued portrayal of the widow as a victim is a consequence of preoccupation with the discourses of coloniality, a crisis of masculinity (Chandra, 1987) and reluctance of a feminist engagement with the systemic structure of Hinduism outside the purview of rendering it patriarchal, casteist, orthodox, violent and oppressive. This phenomenon is aptly exemplified in two areas of representation of widows-literature and films in the Indian context which have continued to amplify the sufferings of the celibate widow. Death-real or imagined has often been written as her fate (Chandra, 1987). 
One of the most recent fictions on Hindu widow- "The Last Color" also depicts death as inevitable for the Hindu widow Noor whose only crime was her audacity to love a girl child from streets of Varanasi and her vow to protect and free her from clutches of poverty and exploitation at all costs. A heart-wrenching scene from Deepa Mehta's film "Water" depicts the sadness and pain in the eyes of an old frail widow due to abstinence from simple joys of life such as eating a sweet. Commenting on the dominance of focus on oppressions of widowhood, Chakravarti and Preeti note that the over-determination has been a "colonial conjecture" which has continued to shape the "ideological field of widowhood" (2001: p. 5).

The specific problem of the portrayal of Vrindavan widows has been, what Foucault calls the reproduction of the "dominant state discourses" (Gilbert \& Powell, 2010: p. 4). The imagination of the Hindu widow as a victim is reproduced in studies conducted both by government ${ }^{1}$ and non-government ${ }^{2}$ agencies in the field who have reiterated the focus on oppression and marginalization of Vrindavan widows. Besides they have offered limited in-depth qualitative insight into how widowhood operates in Vrindavan, the role that the socio-cultural and economic ethos of Vrindavan might play in the life of widows and how widows negotiate the ascribed role of being a Vrindavan widow. The politics of narrativization becomes evident in the choices that agencies and individuals make in terms of selecting aspects of lives of widows that need to be highlighted and those considered not worthy of investigation. It is a vital feminist task to bring within the parameters of feminist knowledge, those aspects of women's lives that are neglected, erased or thought of as too banal to be theorized.

The discourse on widowhood, thus begs for newer inquiries especially foregrounding the voices of the widows themselves that could fragment the pre-determined imaginations. World Bank has laid emphasis on listening to the widows' voices in their report "voices of the poor" (Narayan et al., 2000). Investigation and analysis need to be undertaken into aspects of widow's lives previously neglected. The invisible economic contributions made by widows to the society (UN Women, 2001), widows' coping mechanisms and resilience in the face of socio-cultural and economic oppression, female friendships amongst ageing widows could constitute newer areas of inquiry that could yield remarkable insights into bargains and negotiations within relationships, communities, and social structures that this group of women undertake on a regular basis for their continued sustenance.

\section{Methodological Design}

This study employs feminist research methodology in an attempt to fragment the colonial and patriarchal construction of Vrindavan widows as powerless suf-

${ }^{1}$ See for example Study on Widows at Vrindavan by National Commission for Women, September 2009.

${ }^{2}$ See for example Widows in India: Study of Varanasi and Vrindavan by Sulabh International, September 2016. 
ferers by centering their life narratives in their own words. As Nair aptly states, "the history of female experience is not one of powerlessness at all times, since to be less powerful does not equate to being perpetually powerless" (1994: p. 83). To understand the phenomenon of widowhood in Vrindavan the researcher adopted an ethnographical approach. Life narratives were collected in the form of audio recordings from 52 widows living across three shelter homes or ashrams $s^{3}$ and subsequently translated and transcribed. In-depth unstructured interviews and participant observation were used as research tools to ask open-ended questions on various aspects of widows' lives and to observe how widows conduct their day-to-day living. The questions covered various aspects of their lived realities such as socio-economic position, regional and caste affiliation, life in natal family before marriage and life in conjugal family after marriage, the experience of widowhood and the changes it entailed in their lives, decision to come to Vrindavan and life in Vrindavan. The interviews yielded profound insights into rich and complex life histories of widows. Findings reiterated that a Hindu widow faces triple marginalization - by virtue of being a woman, a Hindu and an upper-caste widow ${ }^{4}$. Further, they revealed that being in the thick of adversities created by their socio-economic and cultural realities women engaged in negotiations and "patriarchal bargains" a term coined by Kandiyoti to denote the process of "optimizing life options with varying potential for active or passive resistance in the face of oppression" (1988: p. 274).

\section{Widowhood in Vrindavan-A Closer Engagement}

Qualitative analysis of the narratives revealed that widows who decide to spend their lives in Vrindavan belonged to some of the most under-developed states in India such as West Bengal and Bihar where they faced substantial poverty. They are ageing women; having spent the prime of their lives in the roles of wife, daughter-in-law and mothers which mostly entailed intensive care giving with no monetary ramifications. It was considered a part of their duty as a good Hindu woman. Poverty, old age and its associated malnourishment wore out the women over several years. Their health was marred by various kinds of illnesses, the treatment of which was an increased potential financial incurrence for their care givers. They belonged to caste groups-both high and low-that marginalize their widows-especially high castes to maintain caste purity. Thus they practiced severe restrictions and were treated as the lowest members of their respective communities. Poverty in the natal families along with more number of siblings and the practice of son preference resulted in negligible amount of education-an instrument for future fulfillment of self-reliance. For a woman to

\footnotetext{
${ }^{3}$ According to Oxford Languages an ashram denotes (especially in South Asia) a hermitage, monastic community, or other place of religious retreat.

${ }^{4}$ This is not to say that being a Hindu and belonging to an upper caste does not bestow its privileges upon Indian women. In fact it constitutes a certain status in a Hindu majoritarian state. But the case of the upper caste Hindu widow is quite precarious as already demonstrated by feminists like Uma Charavarti and Tanika Sarkar.
} 
work is still considered disreputable in a large number of Indian families thus very little exposure was gained to the world outside the household. Even for women hailing from middle class or affluent households, education for girl child was not a priority. Taking up the role of the care giver even before marriage due to early death of their mothers was a common trend that directed all their capacities to support their father and young siblings. Being married off at a very young age meant transitioning from the role of care giving at natal household to the conjugal household where the latter was to a much greater degree. Disintegration of the joint family structure and rise of nuclear family unit due to the various economic forces consolidated their position as a "burden" on the household with the demise of the husband. The unfavorable realities of property rights for women which merely exist as poorly implemented laws, lack of any financial assets such as monetary savings or gold added to the precarity of their situation. Further, two pillars of their assumed support system of widowhood-brothers and sons, were caught up in the same downward spiral of poverty. Issues of harassment, abuse, cheating and violence mark the widowhood experience of the widows before coming to Vrindavan. In the face of these adversities, a pious life of religiosity offers itself as a feasible refuge to escape from diverse marginalities.

Vrindavan is home to a large number of ancient and contemporary temples, river banks, hills and forests rendered sacred due to inscription of life events of Krishna on the landscape of the town which attract thousands of religious tourists around the year. Vrindavan was completely forgotten till it was rediscovered by Chaitanya Mahaprabhu, a $15^{\text {th }}$ century Indian saint in 1515 when he visited Vrindavan with the purpose of locating the lost holy places associated with Krishna. The influx of widows in the town, especially from West Bengal, is believed to originate after the arrival of the said saint.

Around 50 - 60 years earlier widows would come to Vrindavan, stay in premises of the numerous temples, were sympathised by the residents who would offer them shelter and food free of cost. Popularity of Vrindavan as a holy site grew with the growth in popularity of the ISKON (International Society for Krishna Consciousness) movement and the small distant town started receiving huge foot falls especially from foreign tourists who stayed on for months in their quest for spirituality. The prices of the goods and real estate soared once Vrindavan started becoming internationally renowned. This created difficulties for the aged widows as residents started charging rent and food was not available as easily as before. Many widows had to move to living on streets increasing their visual presence in streets of Vrindavan. With their continued presence they gradually became incorporated into the cultural ethos of Vrindavan. They became integral to the spiritual economy of the town as their corporeal presence in the space and place of Vrindavan steadily invoked the conjecture of the ill-fated, doomed widow waiting to be rescued from the misfortunes of widowhood. The Hindu pilgrims, too aware of her miseries due to her ominous omnipresence in 
Hindu "public consciousness" (Chakravarty \& Preeti, 2001: p. 4) and too discomforted by her mere existence engaged in charity towards widows in accordance with the Hindu concept of daana (religious charity) (Cole, 1991: pp. 101-105) and punya (the notion of accumulation of good deeds in Hinduism) through daana. The transaction of charity grew multifold and became formalized and institutionalized. With international tourism the word about the plight of the widows also reached far and wide and led to civil society intervention and setting up of government and NGO ashrams for the widows with provisions to provide food, shelter and other amenities.

The widows coming to Vrindavan envision a life of dignity and security, free from the hardships of poverty, violence, forced labor and negligence. For them, Vrindavan is a nurturing and providing land, where they aim to take their last breath and hopefully be free from suffering of the human form and cycle of birth and death (in accordance with the Hindu belief in reincarnation). The matrix of oppression along with a sense of being a good Hindu widow who ought to spend the rest of her life being a devout woman immersed in the devotion of God until her death, encourages women to come to Vrindavan.

The decision to come to Vrindavan is undertaken by widows due to adverse economic and familial circumstances. They have a negligible say in how they would like to spend their lives as widows. Asserting self-interest is a task that comes to women with a lot of difficulty. In a context where the reality of women's decision-making still remains dismal; even though they majorly contribute to the productive and reproductive labor of the household yet remaining outsiders to decision making processes, women resort to mystical idioms and ascribe the decision to move to Vrindavan to divine will. Ramberg (2014: p. 42) considers such provenances a form of women's "creative cultural agency". For example, a widow, extremely distressed by the disappearance of her very young son and on a visit to see her friend shared her experience of receiving a divine vision. "I was resting and my friend's daughter lay beside me. Suddenly the girl had a vision and in a possessed state she said that my bhakta (devotee) has come to this house. She won't stay here for long, she will leave to spend her life in Vrindavan and wouldn't return from there. Mother (referring to Goddess Durga, a revered female Goddess in Hinduism) thus gave the command." As widows commonly put it "I did not come on my own accord, it was Radha Rani (Krishna's divine companion) who got me here!"

Word of mouth constitutes the primary source of information about Vrindavan for the widows. They are informed by their Gurus (spiritual teacher), relatives, friends, neighbors, unknown people and other widows about possibility of a dignified and religious life in Vrindavan. Women are usually helped in their journey to Vrindavan by police or by random strangers in the form of money, guidance, directions, free rides, some even reported that strangers personally accompanied them since they did not know how to undertake the journey to Vrindavan. A widow who was facing violence on a daily basis at the hands of her 
daughter-in-law shared her experience. "There was a man in my community, a very good man. He said 'mother', though it's not my right but I'll still speak. Why are you getting your bones broken by these people? If your hands will not work how will you eat? I will leave you in Vrindavan. I can do this much. There you can at least beg and eat. He left me in Vrindavan."

Widows arriving in Vrindavan either rent a space, are referred to an ashram or end up on the streets though majority of widows manage to find a shelter in an ashram. Women in the non-governmental ashrams are allotted a small space, a bed and an individual cupboard to hold their belongings. The rooms are either shared amongst 2 - 3 women or more women in a dormitory set up. Their belongings usually consist of white sarees (Indian dress) in accordance with the prescribed dress code. Other articles predominantly consist of religious books, pamphlets, calendars and photos that they have collected over years visiting holy places or have gathered visiting various temples in Vrindavan.

Widows make meaning of their loss and grief by resorting to the concept of fate or bhagya, another prominent concept in Hinduism. Being deeply steeped in Hindu religiosity they unquestioningly accept their fate as a widow and hold their destiny responsible for their plight. A widow rationalized the death of her husband in the following manner. "Those who are good natured they pass away quickly. You would see that saints and ascetics don't live for long. Those who are evil natured live long lives. The way things work in the Bhagwat (sections from Bhagwat Purana, an ancient Hindu text consisting of episodes from Hindu mythological epics such as Mahabharata and Ramayana), life also unfolds in a similar fashion. Otherwise I wouldn't be living here in Vrindavan. I am pained by the fact that my husband is no more. My children are alive and doing well and I am here."

Conforming to the prevalent religious ethos in Vrindavan constitutes the means towards furthering one's survival. How well a widow will flourish in Vrindavan is determined by how malleable she is to adapt herself to the socio-cultural construct of a Vrindavan widow. Thus performativity of ideal widowhood constitutes a vital task. Vrindavan widowhood replicates practices of upper-caste widowhood. Renouncing tamas (heat) generating food such as onion, garlic, eggs, meat and fish, renouncing bodily adornments, wearing white, abstaining from sexual relationships and adopting a life of devout religiosity are covert norms of widowhood as practiced in Vrindavan. Widows imbibe specific norms of observing widowhood in Vrindavan through observing their fellow widows and attending religious sermons that take place in Vrindavan on a regular basis. When inquired about how women gained the knowledge about do's and don'ts of widowhood a common response was "this is how things are". A widow reiterated "When one becomes a widow, no one wears colourful clothes. It's a commonly known thing. In any big auspicious celebration or a marriage they would not call me. This is how things are".

Widows strive to constitute an authentic religious pious self to gain legitimacy 
as a Vrindavan widow. Molding of the self happens through adherence to a daily routine that is fairly religious in nature. A widow shared her typical day during the interview "After waking up I make my bed then I bathe, wake up the deity and offer pooja (ritual worship). After that I sing bhajans (devotional songs) with other women. Subsequently, I come back to my room and eat the flat bread and sugar and then I cook for the day. In the evening I sing bhajans again and then I come to my room and read the holy book. I don't watch TV or play Ludo (board game) like others here. I am mostly devoted to my deity. At times I watch religious themed film which comes on television, otherwise I don't." Thus the daily life is ritualistic and predominated by repetitive daily chores that are closely tied to women's religious beliefs about the duties and moral obligations of a widow. Mahmood (2011) has discussed the significance of ritual repetition in lives of Muslim women participating in the piety movement in Egypt. As Turner (2019: p. 292) simplifies her theorization "One becomes a good or virtuous person by the habitual performance of good behavior, or pious practices produce pious women." A widow described the significance of ritual repetition according to her understanding. "Naam dharna" as she called it roughly translating into imbibing the divine name was explained as follows. "Sometimes our mind wanders. Saints have said get hold of one name, one practice and that's all. We will have to learn that first. Why do we go to Ganga or Yamuna (sacred rivers according to Hinduism), so that our heart becomes pure (the notion of shuddhi; taking a dip in rivers mentioned above is believed to purify one's consciousness). Learn what the root is. Hold on to it. Don't spend your time unnecessarily. 50 malas (referring to ritual chanting of God's name using rosary beads to keep a track of repetitions), minimum, every day. It is a blessing, one name. Radhe Radhe. She gives power, beauty, she runs everything. There is much power in the name."

The performativity of widowhood is not only an intra-personal task of cultivating devoutness. The external performance is equally significant. The donning of the white garb, wearing of the tulsi mala (sacred necklet made of seeds of holy basil, an ornament considered dear to Krishna), marking the forehead with sandalwood tilak (sacred marking on forehead drawn in the shape of $\mathrm{U}$ ) marks the embodiment of the widow persona. The personal space is inscribed by the symbolism associated with Krishna. Women decorate the tops of their allocated cupboards as their deity's alter and each widow strives to make her alter grand, decorated and attractive with framed pictures and idol of Krishna, religious books and myriad trinkets. These are proudly displayed to the guests who visited the ashrams. The symbolism associated with Krishna is also imbued in the structure of language that women use to communicate. Considering language as "a form of social action, a cultural resource, and a set of socio cultural practices" (Schieffelin, 1990: p. 16) widows of Vrindavan regulate their language and speech to resonate with the linguistic trends followed by commoners. The salutation used to greet each other is Radhe Radhe, upon being asked how they manage to garner food for themselves women often state "I accept and eat 
whatever Radha Rani (queen Radha) gives me." Krishna is referred to as Thakur $j i$, bal gopal or laddu gopal which are the prevailing names for addressing Krishna in Vrindavan, the latter two especially referring to Krishna in an infant form. On many occasions women described themselves as Gopis (friends of Krishna) or Meera (renowned devotee in love with Krishna). Their conversations are infused with stories and moral teachings which they imbibe from listening to sermons. Singing bhajans (devotional songs) and regular visits to temples constitutes other significant acts of widowhood performativity.

The space and place of Vrindavan enables negotiations pertaining to norms of widowhood as long as the performing widow strives towards being an ideal Hindu widow. Whilst some norms become more stringent others are followed with certain leniency. This can be demonstrated with negotiations around dietary regulations. Widows who might have been consuming onion, garlic and non-vegetarian food before coming to Vrindavan practice strict abstinence after coming to Vrindavan. One widow elucidated the same in her conversation with the researcher.

"I: Do you have onions, garlic?

$\mathrm{W}$ : I used to eat it.

I: In your youth would you consume fish?

W: Yes even Brahmins (upper-caste widows) have it though they have restrictions.

I: so you left onions, garlic and fish after your husband's death?

W: No, after I got to Vrindavan, I wouldn't lie to you"

The same stringent dietary rules become relaxed when there is ritual offering of a bhandara 5 . Food is lavishly prepared with generous use of oils and spices and sweets are served to the widows. Sweets traditionally considered an indulgence for widows is readily available for women in the form of prasad (religious offerings of food) at various temples, bhog (food offered to god) which women prepared themselves for their daily worship apart from the bhandaras. Some ashrams allow widows to cook food for themselves and they prepare a variety of chutneys and fritters to accompany their simple meal. Banerji and Jack (2006) have traced the multifold enhancement of Bengali vegetarian cuisine due to cooking practices of Bengali widows.

The norm of wearing white colored garments is negotiated by ascribing the willingness to wear other colors to family members. Women stated that had benevolent in-laws and relatives who insisted that they don't wear white and don't carry on the mourning. "In older times you had to abide by so many rules, like wearing only white clothes, but my in-laws were kind, they told me that white clothes would not look good on me, that I needn't follow the rule so strictly. They also asked whether I would consider to remarry but I denied. They asked me not to carry the mourning in front of them as it made them sad to see me in ${ }^{5}$ Ritual offering of community food service. Bhandara's are frequently organized in Vrindavan by visitors who want to commemorate a special day, in temples and in various ashrams headed by godmen. 
pain. The one who is gone, is gone. One can't sit idle and mourn him all the time" was one widow's assertion. Another one pitched in stating "as if it is not bad enough that one has lost her husband that she has to put herself through these restrictions".

Being associated with Krishna, the spiritual economy of the town centers around Krishna veneration. Hinduism being a polytheistic religion widows worshipped several Gods and Goddesses before coming to Vrindavan but they switch to Krishna Bhakti (veneration of Krishna) after coming to Vrindavan. The figure of baby Krishna is most commonly venerated since he is believed to have spent his childhood days in and around Vrindavan. Widows are encouraged to establish a personal relationship with Krishna. One widow shared her experience "I was attending the Bhagwat sessions. ${ }^{6}$ On the last day we were asked to establish a relationship with God. I thought to myself what relationship do I need? I don't need a husband since my man died. I am not young so bodily needs don't bother me that much. My body is at peace. I needed a son. I made Krishna my son. The moment I considered him my son, I was at peace." Thus a homogenization of diverse veneration practices belonging to widows of different castes and regions takes place in Vrindavan.

\section{Vrindavan and Its Widows-The Interdependence}

There is a complex and mutually beneficial relationship between Vrindavan and its widows. The base of such an inter-relationship is economic upon which stands the cultural-spiritual super-structure. The Imperial Gazetteer of India recognized two important features of Vrindavan way back in 1881. Firstly, the growth of the place occurred due to development of several Vaishnava cults that venerated Krishna and secondly that the town "depended on pilgrim traffic for its prosperity" (Hunter, 1908: pp. 17-18). These continue to be true in the present time too with religious tourism growing multifold over the years.

The presence of widows has enabled a micro-economy of widowhood in Vrindavan. Apart from the ashrams run by government and private players that provide living support there are other agencies that regulate the donations that comes into Vrindavan as charity for widows. Spiritual tourists often donate money or articles of daily need for widows in bulk to bhajan ashram and seva ashram which are distributed amongst widows on a regular basis. The articles for donations consisting of food items, sweets, grains, pulses, soap, oil, bags, blankets, sarees, sweaters and socks are locally purchased from small scale merchants boosting the local economy.

Vrindavan experiences increased footfall of tourists around months leading to Hindu festivals, especially Janmashtami (celebration of birth of Krishna), Holi (Hindu festival of colors) and Diwali (Hindu festival of lights). Aside from the fact that the festivals hold a place of reverence in the consciousness of Hindus participation of widows especially in the latter two events constitutes a visual

${ }^{6}$ Community reading of scriptures happens in numerous ashrams in Vrindavan, widows regularly attend these sessions. 
spectacle, a "thing to see" in Vrindavan. The trend of widows' participation in festivities was started in early 2000s by NGOs to mark the breaking of cultural taboos such as abstinence from using colors and exclusion from auspicious occasions. Widows playing Holi and celebrating Diwali annually garners immense media attention.

Vrindavan in turn supports the subsistence of the widows. Widows who decide to spend their lives in the town accrue both tangible and intangible benefits. Widows are supported monetarily and otherwise, in their quest for moksha in Vrindavan. They receive pension ranging from rupees 300/- to 2000/- which constitutes a bleak amount thus they engage in myriad other transactions to make ends meet. Few widows have picked up the skill of stitching which they utilize to stitch clothes for the idol of baby Krishna which is one of the most commonly sold articles in shops around temples. They supply it to local vendors for a sum for themselves. Bhajan singing is both a performative devotional exercise and an economic opportunity to earn additional income. Bhajan ashram is a community ashram that conducts bhajan singing sessions and widows from all over Vrindavan take part in it. Women are paid between rupees 5 - 15 for participating in each singing session which takes place every day in the morning and evening. The meagre sum increases in case any devotee has made a monetary donation. Seva ashram is exclusively dedicated to distribution of donation articles amongst widows. The term "baanta-baanti" is employed by widows to refer to the process of collecting and sorting donated articles. Other articles of necessity are often provided for by visitors directly visiting the ashrams housing the widows. A widow shared her experience of collecting her share of donations. "They used to distribute saree and blankets in Bhajan ashram. Yesterday, a seth (a rich person, mostly a businessman) visited our ashram and distributed socks and gave us Rs.10 each. They also distributed biscuits yesterday. They give us a blanket every two years and the year before they gave me a quilt." Additionally, widows receive gifts on the occasion of festivals especially Holi and Diwali which are primarily distributed by the NGOs.

There are numerous ashrams all over Vrindavan that organize recitation of Bhagwat which are sponsored by various patrons on numerous religious occasions. Widows frequently attend these and receive donations contributed by the organizers. Over time women cultivate informal memberships to different ashrams scattered all over Vrindavan which are run by Godmen and religious gurus. They are called upon by their respective ashrams in case there is a bhandara where they are offered a hearty meal and given a share of donations offered by sponsors.

Bhandaras are held frequently in Vrindavan in temple premises, at various ashrams and at the residential facilities. Devotees either offer these on religious occasions or on personal occasions such as celebrating a birthday, anniversary or to commemorate death anniversaries. Bhandaras are organized contractually by

${ }^{7}$ Hindu concept of spiritual salvation that entails freedom from the cycle of birth and death. 
assigning the responsibility of procuring food grains, vegetables, spices and condiments to local contractors and local cooks are hired to prepare the large scale community meals. Additionally, widows visit temples where they receive a share of offerings by devotees. Though begging is looked down upon as a means to earn money some widows admitted to asking for alms to sustain oneself.

Women often engage in barter of articles received through charity. The money received is carefully saved whereas non-monetary donations are frequently exchanged and sold to local shops. For example, some women stated bartering rice for better quality rice or cooking oil at the shops. They have explored the local market and have fixed shops to sell or exchange articles. The money from pension, bhajans, charity, bhandaras and alms is saved to buy items of necessity, used for traveling to their hometown and saved for their own last rites.

The intangible benefits for staying in Vrindavan include enhanced leisure time for the self, help with self-sustaining chores, avenues for engagement in socio-cultural activities, low cost medical aid and development of bonds beyond kinship.

The structure of daily living for widows in Vrindavan primarily involves taking care of the self and immersing oneself in religiousness. For several women this is in contrast with the long arduous hours of labor that they spent in house work before coming to Vrindavan. Leisure time and the freedom to choose what they do with their time constitutes a new found luxury, as long as what they decide to do befits the overarching structure of a widow's lifestyle. Television is installed at residential ashrams for those who wish to watch it. Women also spend leisure time by playing board games with other women.

Those who are very old or sick are spared from the various chores. These women stated that at home they would not have an option to be idle due to sickness or old age but here they were spared from work if they expressed their unwillingness to participate. Widows have evolved their own strategies to garner help and support for various daily chores. Those who are younger and slightly stronger help the other women in taking care of themselves and running their errands. Women befriended locals to help procure milk, vegetables and medicines.

Women engage in several additional day-to-day activities like tending to gardens, tending and plucking vegetables, tending domesticated animals, washing their clothes and utensils, sweeping and swabbing their area, knitting and making a variety of food for self and others. There are logistical time consuming activities like paper work regarding pension, identity cards and procuring gas cylinders for the purpose of cooking. Where facilities are available women are involved in learning reading and writing, stitching and paper bag making. Medical aid is provided to widows free of cost or at a minimal price. The residential ashrams have weekly visits from doctors to monitor the health conditions of widows. Additionally, hospitals in Vrindavan provide their services at a hugely subsidized cost to the widows. 
Lack of social interaction and social isolation are two worrying issues afflicting the urban elderly in India. These are largely taken care of in Vrindavan. Relationship amongst women are bitter-sweet; on one hand there is fight for resources such as food and space but on the other hand there are friendships and a shared sense of a common fate. Some relationships are nurturing, one widow reported that she had lost interest in cooking for herself since she was very depressed, her friends at the ashram would cook for her and feed her. But all relationships are not cordial. Frequent fights broke out over limited resources such as water or gas cylinders and regional and caste assertions dominate such fights. Other dynamics such as favoritism and corruption in disbursement of pensions or donations are also not uncommon.

There exists a vibrant community life with legitimate space for widows to participate which also offers tangible resources necessary to conduct their day-to-day life in Vrindavan. Most women stated that they did not mind the hardships here since they had more autonomy relatively as compared to their homes. It was a common sentiment as expressed by a widow that they are "living, eating and bathing well, receiving financial support in cash and kind and are taken care of." They also like that their "days are spent singing bhajans and counting the rosary, there is television, ambulance, health facilities, sick are taken care of and allowance is given."

\section{Conclusion}

Vrindavan survives on two things; temples and widows. These two entities are diametrically opposite to each other, still one defines the other. Widows constitute the "other" in Vrindavan. The temples represent all that is auspicious, sacred, celebratory and pious. The widow figure, on the other hand represents the inauspicious and the impious. The auspiciousness of the city is built on the inauspiciousness of the Hindu widow. This phenomenon is not limited to Vrindavan. Across holy cities in India especially in places like Varanasi, widows constitute the spectacle of misfortune. Denton and Collin (2004: p. 10) manage to translate a popular saying in Varanasi "rand, saandh, sidhi, sanyasi, insey bache to seve kaasi" meaning one can enjoy the spiritual fruits of Kashi (Varanasi) after one has managed to successfully avoid widow, bull, steps and numerous mendicants. Though they are faceless they are integral to the spiritual economy of Vrindavan. Visiting Hindus believe performing daan (donation) to help the needy such as widowed women will enhance their karma (spiritual accumulation of good deeds according to Hinduism). While people may consider them inauspicious, they rely on them for rituals to attain salvation. They pay for widows to sing bhajans and conduct bhandaras to feed the widows for spiritual redemption of their dead ancestors. Thus there exists a paradoxical relationship between auspiciousness and inauspiciousness associated with widows in Vrindavan. The maintenance of her precarity is essential for the continuance of cultural and economic transactions that take place in the town. Widows, in turn, do not re- 
main passive recipients of charity. They are an active part of the cultural and spiritual economy of Vrindavan, partaking in everyday negotiations and bargains to survive. Thus the very matrix of religion, that creates a situation of their oppression, also offers interstices for widows to navigate the experience of widowhood in Vrindavan. The norms of Hindu upper-caste widowhood are reconstituted and reproduced through performance of widowhood by Vrindavan widows.

\section{Acknowledgements}

We are indebted to three organizations, Ma Dham, Maitri and Ma Sharda Mahila Ashram in Vrindavan for granting us permission to conduct field work on their premises. This paper wouldn't have been possible without the willingness and eagerness of the 52 participants, who narrated the intricacies of their lives and shared their stories of grief, joy, and survival. Thank you for keeping us grounded.

\section{Conflicts of Interest}

The authors declare no conflicts of interest regarding the publication of this paper.

\section{References}

Ambedkar, B. R. (1979). Castes in India: Their Mechanism, Genesis and Development. In B. Ambedkar (Ed.), Writings and Speeches (Vol. 1, pp. 3-22). Bombay: Education Department, Government of Maharashtra.

Banerji, C., \& Jack, I. (2006). What Bengali Widows Cannot Eat. In C. Banerji, The Hour of the Goddess: Memories of Women, Food and Ritual in Bengal (pp. 95-104). New Delhi: Seagull Books.

Chakravarti, U. (1995). Gender, Caste and Labor: Ideological and Material Structure of Widowhood. Economic and Political Weekly, 30, 2248-2256.

Chakravarti, U., \& Preeti, G. (2001). Introduction. In U. Chakravarti, \& G. Preeti (Eds.), Shadow Lives: Writings on Widowhood (pp. 7). New Delhi: Zubaan.

Chandra, S. (1987). Conflicted Beliefs and Men's Consciousness about Women: Widow Marriage in Later Nineteenth Century Indian Literature. Economic and Political Weekly, 22, WS55-WS62.

Chen, M. A. (1998). Widows in India: Social Neglect and Public Action. New Delhi: Sage Publications.

Clémentin-Ojha, C. (1988). Outside the Norms: Women Ascetics in Hindu Society. Economic and Political Weekly, 23, WS34-WS36.

Cole, W. O. (1991). Moral Issues in Six Religions (pp. 104-105). Bath: The Bath Press.

Das, N. D. (1886). The Hindu Widow. The Nineteenth Century and After: A Monthly Review, 20, 364-373.

Denton, L. T., \& Collin, S. (2004). Introduction. In L. T. Denton (Ed.), Female Ascetics in Hinduism (pp. 1-22). Albany, NY: State University of New York Press.

Ganapathy, R. (2019). Act for Your Life: Widows in Vrindavan. Ecumenica, 12, 14-27. https://doi.org/10.5325/ecumenica.12.1.0014 
Gilbert, T., \& Powell, J. L. (2010). Power and Social Work in the United Kingdom: A Foucauldian Excursion. Journal of Social Work, 10, 3-22. https://doi.org/10.1177/1468017309347237

Hunter, W. W. (1908). Brindaban. In The Imperial gazetteer of India (Vol. 9, pp 17-18). Oxford: Clarendon Press.

Kandiyoti, D. (1988). Bargaining with Patriarchy. Gender \& Society, 2, 274-290. https://doi.org/10.1177/089124388002003004

Králová, J. (2015). What Is Social Death? Contemporary Social Science, 10, 235-248. https://doi.org/10.1080/21582041.2015.1114407

Leslie, J. (1995). Translated “Stridharmapaddhati” (p. 303). New Delhi: Penguin Group.

Macdonell, A. (1929). Vidh-ávâ. In A. A. Macdonell (Ed.), A Practical Sanskrit Dictionary with Transliteration, Accentuation, and Etymological Analysis Throughout (pp. 284). London: Oxford University Press.

Mahmood, S. (2011). Politics of Piety: The Islamic Revival and the Feminist Subject. Princeton, NJ: Princeton University Press. https://doi.org/10.2307/j.ctvct00cf

Mani, L. (1998). Contentious Traditions: The Debate on Sati in Colonial India. Oakland, CA: University of California Press. https://doi.org/10.1525/9780520921153

Massey, D. (2013). Introduction. In Space, Place and Gender (p. 186). Minneapolis, MN: University of Minnesota Press.

Mayo, K. (2000). Mother India (p. 78). Sinha, M. (Ed.), Ann Arbor, MI: The University of Michigan Press. https://doi.org/10.3998/mpub.10490

Nair, J. (1994). On the Question of Agency in Indian Feminist Historiography. Gender \& History, 6, 82-100. https://doi.org/10.1111/j.1468-0424.1994.tb00196.x

Narayan, D., Patel, R., Schafft, K., Rademacher, A., \& Koch-Schulte, S. (2000). Voices of the Poor: Can Anyone Hear Us? (pp. 5). Washington DC: World Bank. https://doi.org/10.1596/0-1952-1601-6

Olson, C. (2008). Celibacy and Human Body: An Introduction. In C. Olson (Ed.), Celibacy and Religious Traditions (pp. 3-20). New York: Oxford University Press. https://doi.org/10.1093/acprof:oso/9780195306316.003.0001

Rajan, S. R. (1993). Representing Sati: Continuities and Discontinuities. In Real and Imagined Women (p. 52). London: Routledge.

Ramberg, L. (2014). Yellamma and Her Sisters. In Given to the Goddess: South Indian Devadasis and the Sexuality of Religion (pp. 39-71). Durham, NC: Duke University Press. https://doi.org/10.1515/9780822376415

Schieffelin, B. B. (1990). The Give and Take of Everyday Life: Language, Socialization of Kaluli Children (p. 16). No. 9, New York: Cambridge University Press.

Shandilya, K. (2017). Desire, Death, and the Discourse of Sati: Bankimchandra Chatterjee's Krishnakanter Uil and Rabindranath Tagore's Chokher Bali. In Intimate Relations: Social Reform and the Late Nineteenth-Century South Asian Novel (pp. 4-20). Evanston, IL: Northwestern University Press.

Spivak, G. C. (1994). Can the Subaltern Speak? In P. Williams, \& L. Chrisman (Eds.), Colonial Discourse and Post-Colonial Theory: A Reader (p. 93). Hertfordshire: Harvester Wheatsheaf.

Turner, B. S. (2019). Piety, Practice and Habitus: Saba Mahmood's Dialogue with Aristotle and His Legacy. Sociology of Islam, 7, 289-300.

https://doi.org/10.1163/22131418-00704005

UN Women (United Nations Entity for Gender Equality and the Empowerment of 
Women) (2001). Women 2000: Widowhood: Invisible Women Secluded or Excluded (p. 3). New York: United Nations Entity for Gender Equality and the Empowerment of Women.

Wadley, S. (1995). No Longer a Wife: Widows in Rural North India. In L. Harlan, \& P. B. Courtright (Eds.), From the Margins of Hindu Marriage: Essays on Gender, Religion, and Culture (pp. 92-118). Oxford: Oxford University Press. 